\title{
Assessment of Genotoxic and Cytotoxic Hazards in Brain and Bone Marrow Cells of Newborn Rats Exposed to Extremely Low-Frequency Magnetic Field
}

\author{
Monira M. Rageh, Reem H. EL-Gebaly, and Nihal S. El-Bialy \\ Department of Biophysics, Faculty of Science, Cairo University, Giza 12013, Egypt \\ Correspondence should be addressed to Monira M. Rageh, monirarageh@yahoo.com
}

Received 23 May 2012; Accepted 10 August 2012

Academic Editor: Brynn Levy

Copyright ( $) 2012$ Monira M. Rageh et al. This is an open access article distributed under the Creative Commons Attribution License, which permits unrestricted use, distribution, and reproduction in any medium, provided the original work is properly cited.

\begin{abstract}
The present study aimed to evaluate the association between whole body exposure to extremely low frequency magnetic field (ELF$\mathrm{MF}$ ) and genotoxic , cytotoxic hazards in brain and bone marrow cells of newborn rats. Newborn rats (10 days after delivery) were exposed continuously to $50 \mathrm{~Hz}, 0.5 \mathrm{mT}$ for 30 days. The control group was treated as the exposed one with the sole difference that the rats were not exposed to magnetic field. Comet assay was used to quantify the level of DNA damage in isolated brain cells. Also bone marrow cells were flushed out to assess micronucleus induction and mitotic index. Spectrophotometric methods were used to measure the level of malondialdehyde (MDA) and the activity of glutathione (GSH) and superoxide dismutase (SOD). The results showed a significant increase in the mean tail moment indicating DNA damage in exposed group $(P<0.01,0.001,0.0001)$. Moreover ELF-MF exposure induced a significant $(P<0.01,0.001)$ four folds increase in the induction of micronucleus and about three folds increase in mitotic index $(P<0.0001)$. Additionally newborn rats exposed to ELF-MF showed significant higher levels of MDA and SOD $(P<0.05)$. Meanwhile ELF-MF failed to alter the activity of GSH. In conclusion, the present study suggests an association between DNA damage and ELF-MF exposure in newborn rats.
\end{abstract}

\section{Introduction}

Considerable attention has been focused on the effects of the electromagnetic field (EMF) due to its wide-ranging use in everyday life. Wertheimer and Leeper [1] showed a possible relationship between electrical power lines and childhood cancer. Other studies have been carried out to investigate the biological effects of extremely low-frequency electromagnetic fields (ELF-EMFs). However, the results obtained are contradictory, and a comparison between them is difficult, because of the many differences in exposure parameters (periodicity of the exposure, flux intensity, and endpoint are investigated) [2].

Nevertheless, there is an increase in the number of studies detecting the genotoxic effects upon exposure to ELF-MF. Lai and Singh $[3,4]$ and Svedenstål and coworkers $[5,6]$ have reported that whole body exposure to power frequency of 10,100 , and $500 \mu \mathrm{T}$ MF can result in DNA single- and double-strand breaks (DSBs) in the brains of rodents. Such
DNA double-strand breaks are considered as the most potent form of DNA damage which can induce genomic instability. Unrepaired DSBs cause cell cycle arrest and apoptosis. Moreover, insufficient or incorrect repair of DSBs can lead to carcinogenesis due to translocations, inversions, or deletions. Other studies conducted on mouse m5S cells and human cells detected a significant dose-dependent increase of chromatid-type chromosomal aberrations at 5, 50, and $400 \mathrm{mT}$ [7]. Also Pasquini et al. [8] observed an increased frequency of micronuclei in Jurkat cells exposed for $24 \mathrm{~h}$ to $50 \mathrm{~Hz}$ and $5 \mathrm{mT}$ magnetic field.

Ager and Radul [9] studied the effects of ELF-MF on mitotic recombination in Saccharomyce scerevisiae and found no effect. Antonopoulos et al. [10] found that incubation of peripheral blood culture upon exposure to an electromagnetic field (EMF, $50 \mathrm{~Hz}$, and $5 \mathrm{mT}$ ) leads to stimulation of cell proliferation in lymphocytes but has no influence on the frequencies sister chromatid exchange. 
Exposure to magneticfield (MF) induced changes in the activity of some enzymes involved in the antioxidant system, and the formed damages are due to an imbalance between the activities of an oxidant agent and the antioxidant system within the cell. Although oxygen is required for many important aerobic cellular reactions, it may undergo electron transfer reactions, which generate highly reactive membrane-toxic intermediates such as superoxide, hydrogen peroxide, or hydroxyl radical. The observed cytotoxicity is related to reactive oxygen species (ROS), hydrogen peroxide $\left(\mathrm{H}_{2} \mathrm{O}_{2}\right)$, and hydroxyl radical which are produced by various factors. These reactive species cause oxidative damage to cell membrane, increase in oxygen radical's production, and permit leakage of enzymes leading to organ damage $[11,12]$.

Living cells have evolved numerous defense mechanisms to neutralize the harmful effects of free radicals $[13,14]$. The antioxidant defense system includes enzymes such as superoxide dismutase (SOD) and other scavengers such as glutathione (GSH). Di Loreto et al. [15] investigated the effects of exposures to two different $50 \mathrm{~Hz}$ sinusoidal ELFMFs intensities $(0.1$ and $1 \mathrm{mT})$ in maturing rat cortical neurons' major antioxidative enzymatic and nonenzymatic cellular protection systems, membrane peroxidative damage, as well as growth factor, and cytokine expression pattern. The results showed that ELF-MFs affected positively the cell viability and concomitantly reduced the levels of apoptotic death in rat neuronal primary cultures, with no significant effects on the main antioxidative defenses.

Therefore, the present study was designed to evaluate the effect of continuous exposure to $50 \mathrm{~Hz}$ and $0.5 \mathrm{mT}$ MF on the brain and bone marrow of newborn rats by measuring some parameters indicative of oxidative stress (lipid peroxidation MDA, superoxide dismutase SOD, and glutathione GSH) and on oxidative DNA damage that subsequently cause injure in the brain and bone marrow cells.

\section{Materials and Methods}

2.1. Animals. Animals were housed and maintained according to guidelines for the Care and Use of Laboratory Animals 1996 [16] and approved by the Animal Ethics Committee at Cairo University. Briefly, timed pregnant Wistar rats were purchased from the National Center of Researches in Egypt and gave birth at the animal house of Cairo University. They were maintained for one week in the laboratory for adaptation. Adult female rats with their newborn were housed in plastic cages with free access to water and standard chow diet. They were also maintained in a controlled environment (humidity $50 \% \pm 5$ and temperature $25^{\circ} \mathrm{C}$ ) with $12 \mathrm{~h}$ light cycle. All animal groups were housed in clean first hand cages under standard condition in a separate laboratory which belongs to animal care unit.

2.2. Magnetic Field Exposure. The exposure was performed using a magnet with a fixed magnetic field value of $0.5 \mathrm{mT} \pm$ 0.025 . The magnetic field was generated by a solenoid carrying current of 18 ampere at $50 \mathrm{~Hz}$ from the main supply (220-230 Volt) via a variac (made in Yugoslavia). The

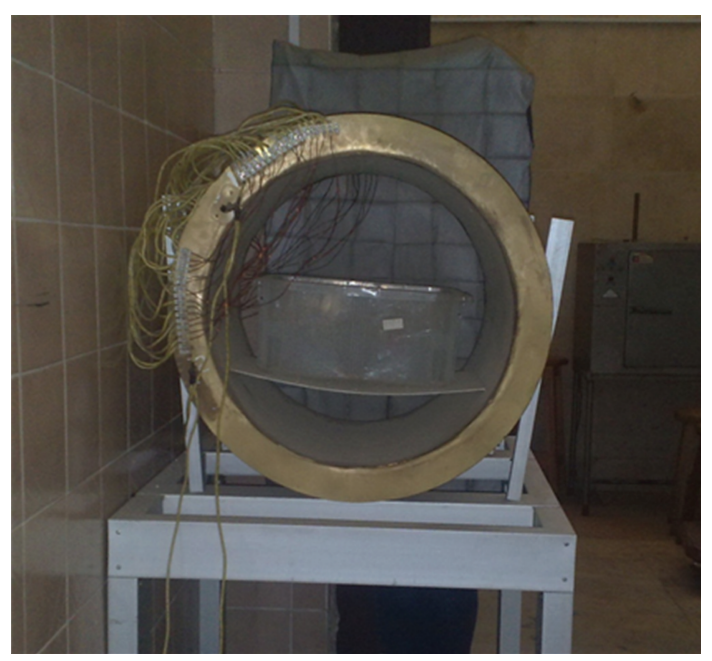

Figure 1: Experimental setup of the exposure system.

magnet consisted of a coil with 320 turns made of electrically insulated $0.8 \mathrm{~mm}$ copper wire. The coil was wounded around a copper cylinder of $2 \mathrm{~mm}$ thickness, $40 \mathrm{~cm}$ diameter, and $40 \mathrm{~cm}$ length. The cylinder wall was earthed to eliminate the electric field (Figure 1). The magnetic field was measured at different locations to find out the most homogenous zone inside the solenoid core. This was done using Gauss/Tesla meter with probe T-4048 manufactured by Bell Technologies Inc. (Orlando, FL, USA).

Plastic cages $(40 \times 25 \times 20 \mathrm{~cm})$, containing 7 adult female rats and their newborns $(n=60)$, were placed in the middle of the exposure chamber prior to MF exposure. When the newborns reached 10 days of age, they were randomly divided into two groups of 30 each: one control (sham) and one exposed. The latter group has been exposed to $50 \mathrm{~Hz}$, $0.5 \mathrm{mT} \pm 0.025 \mathrm{MF}$ for 30 days $24 \mathrm{~h}$ per day. The control group was treated like the exposed group with the sole difference that it was not exposed to magnetic field. The two groups were treated equally considering light and food. The temperature and humidity were monitored continuously throughout the experimental period. This ensures that the control and the exposed animals were maintained in the same condition. During the experimental period, cleaning and changing water and food were done to all animals two times daily. The field was switched off during cleaning the cages.

After 30 days of exposure, the two groups of newborn rats were sacrificed by decapitation. Ten newborn rats from each group were used for micronucleus test, comet assay, and histopathological examination. Another 10 newborn rats were used for mitotic index determination and lastly 10 newborn rats were maintained for oxidative stress evaluation.

2.3. Biochemical Estimation. Ten newborn rats from both control and exposed groups were sacrificed by decapitation, and the brains were dissected and prepared for biochemical analyses. Superoxide dismutase (SOD) assay relies on the ability of the enzyme to inhibit the phenazine 
TABLE 1: The levels of MDA ( $\mu \mathrm{mol} / \mathrm{L}), \mathrm{GSH}(\mathrm{mg} / \mathrm{dl})$ and SOD (U/g tissue) in the brain of control newborn rats and those exposed to $50 \mathrm{~Hz} 0.5 \mathrm{mT}$ MF for 30 days $24 \mathrm{~h} /$ day. Each value was expressed as mean of 10 rats \pm standard error.

\begin{tabular}{lcc}
\hline Parameters & Control group & Exposed group \\
\hline $\mathrm{MDA}(\mu \mathrm{mol} / \mathrm{L})$ & $0.113 \pm 0.017$ & $0.302 \pm 0.021^{*}$ \\
$\mathrm{GSH}(\mathrm{mg} / \mathrm{dl})$ & $0.033 \pm 0.003$ & $0.030 \pm 0.000$ \\
$\mathrm{SOD}(\mathrm{U} / \mathrm{g}$ tissue $)$ & $182.33 \pm 8.192$ & $263.33 \pm 12.019^{*}$ \\
\hline
\end{tabular}

${ }^{*}$ Significant difference in comparison with the corresponding control at $\alpha=0.05(P<0.05)$.

methosulphate-mediated reduction of nitroblue tetrazolium dye and measured at $560 \mathrm{~nm}$ [17]. Glutathione (GSH) assay is based on the reduction of 2-nitrobenzoic acid with glutathione to produce a yellow compound measured at $405 \mathrm{~nm}$ [18]. Lipid peroxidation was measured by estimating the amount of malondialdehyde (MDA) according to Uchiyama and Mihara [19], and the assay depends on the colorimetric reaction of MDA with thiobarbituric acid giving a pink complex that can be measured at $532 \mathrm{~nm}$.

2.4. Histopathological Examination. The brains of newborn rats from control and exposed groups were dissected, removed, and fixed in 10\% neutral formalin. Then, they were embedded in paraffin blocks, sectioned and stained with hematoxylin and eosin (H\&E).

All brain tissue sections were examined using light microscope (CX31 Olympus microscope, Tokyo, Japan) connected with digital camera (Canon).

2.5. Comet Assay (Single Cell Gel Electrophoresis). Comet assay (single cell gel electrophoresis) is considered as a rapid, simple, visual, and sensitive technique to assess DNA fragmentation typical for toxic DNA damage and early stage of apoptosis [20,21]. The comet assay was performed under alkaline conditions ( $\mathrm{PH}>13$ ) according to the method developed by Singh et al. and Tice et al. [22, 23]. Briefly, a small piece of brain tissues $(n=10)$ from each group were placed in $1 \mathrm{~mL}$ cold HBSS containing $20 \mathrm{mM}$ EDTA (ethylenediaminetetraacetic acid)/10\% DMSO (dimethylsulfoxide, Qualigens, CPW59). The tissues were minced into fine pieces and let settled. $5 \mu \mathrm{L}$ of aliquot was mixed with $70 \mu \mathrm{L}$ of $0.7 \%$ low melting point (LMP) agarose (Sigma, A9414). This agarose was prepared in $\mathrm{Ca}^{2+}, \mathrm{Mg}^{2+}$ free PBS (phosphate buffered saline, HiMedia, TS1006) at $37^{\circ} \mathrm{C}$ and placed on a microscope slide, which was already covered with a thin layer of $0.5 \%$ normal melting point (NMP) agarose (HiMedia.RM273). After cooling at $4^{\circ} \mathrm{C}$ for $5 \mathrm{~min}$, slides were covered with a third layer of LMP agarose. After solidification at $4^{\circ} \mathrm{C}$ for $5 \mathrm{~min}$, slides were immersed in freshly prepared cold lysis solution $(2.5 \mathrm{M} \mathrm{NaCl}, 1 \mathrm{mM} \mathrm{Na} 2$ EDTA, $10 \mathrm{mM}$ tris base, $\mathrm{pH} 10$, with $1 \%$ Triton $\mathrm{X}-100$ and $10 \%$ DMSO added just before use) at $4^{\circ} \mathrm{C}$ for at least $1 \mathrm{~h}$. Following lyses, slides were placed in a horizontal gel electrophoresis unit and incubated in fresh alkaline electrophoresis buffer (1 $\mathrm{mM} \mathrm{Na} \mathrm{N}_{2}$ EDTA, $300 \mathrm{mM} \mathrm{NaOH}, \mathrm{pH} 13$ ). Electrophoresis was conducted for $30 \mathrm{~min}$ at $24 \mathrm{~V}(\sim 0.74 \mathrm{~V} / \mathrm{cm})$ and $300 \mathrm{~mA}$ at $4^{\circ} \mathrm{C}$. Then, the slides were immersed in neutralized buffer (0.4 MTris-HCl, $\mathrm{pH} 7.5)$ and gently washed three times for $5 \mathrm{~min}$ at $4^{\circ} \mathrm{C}$. All the above procedures were performed under dimmed light to prevent the occurrence of additional DNA damage. Comets were visualized by $80 \mu \mathrm{L}, 1 \mathrm{X}$ ethidium bromide staining (Sigma E-8751) and examined at 400x magnification using a fluorescent microscope.

Comet 5 image analysis software developed by Kinetic Imaging, Ltd. (Liverpool, UK) linked to a CCD camera was used to assess the quantitative and qualitative extent of DNA damage in the cells by measuring the length of DNA migration and the percentage of migrated DNA. Finally, the program calculates tail moment. In all the samples, 100 cells were analyzed and classified into 5 types ( $0-4)$ depending on their tail moment. Type 0 represents the cells without visible damage, while cells of type 4 have total degradation of DNA (long, broad tail, and poorly visible head of the comet). Types 1, 2, and 3 represent the symptoms of increasing DNA damage. To calculate the extent of DNA damage, three types of the comet: numbers 2,3 , and 4 were selected.

2.6. Micronucleus Test. Bone marrow slides for micronucleus assay from 10 newborn rats of each group were prepared and stained according to the method described by Schmidt [24] using the modifications of Agarwal and Chauhan [25]. Bone marrow was flushed out from tibias using $1 \mathrm{~mL}$ fetal calf serum and centrifuged at $2000 \times \mathrm{g}$ for $10 \mathrm{~min}$. The supernatant was discarded. Evenly spread bone marrow smears were stained using the May-Grunwald and Giemsa protocol. Slides were scored at a magnification of $1000 \mathrm{x}$ using light microscope (CX31 Olympus microscope, Tokyo, Japan). 2000 polychromatic erythrocytes per animal were scored, and the number of micronucleated polychromatic erythrocytes (MNPCE) was determined. In addition, the number of polychromatic erythrocytes (PCEs) was counted in fields that contained 100 cells (mature and immature) to determine the score of PCE and normochromatic erythrocytes (NCEs).

2.7. Mitotic Index Determination. Slides were prepared according to the method described by Adler [26] with some modification. Briefly, 10 newborn rats (from control and exposed groups) were injected intraperitoneally (i.p.) with colchicine $(2 \mathrm{mg} / \mathrm{Kg}) 2$ hours prior to tissue sampling. Bone marrow cells were collected from the tibia by flushing in $\mathrm{KCl}\left(0.075 \mathrm{M}\right.$, at $\left.37^{\circ} \mathrm{C}\right)$ and incubated at $37^{\circ} \mathrm{C}$ for $25 \mathrm{~min}$. Material was centrifuged at $2000 \times \mathrm{g}$ for $10 \mathrm{~min}$, and fixed in acetomethanol (acetic-acid: ethanol. 1:3, v/v). Centrifugation and fixation (in the cold) were repeated five times at an interval of $20 \mathrm{~min}$. The material was resuspended in a small volume of the fixative, dropped onto chilled slides, lame dried, and stained the following day in $5 \%$ buffered Giemsa ( $\mathrm{pH}$ 6.8). Slides were scored at a magnification of 1000x using light microscope (CX31 Olympus microscope, Tokyo, Japan). At least 1000 cells were examined for each rat and the number of dividing cells including late prophase and metaphase was determined. The mitotic activity is expressed 


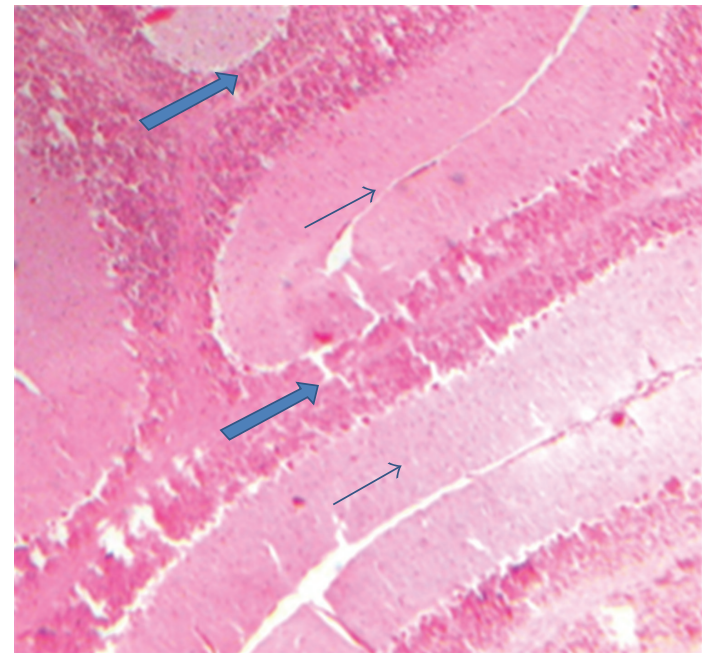

(a)

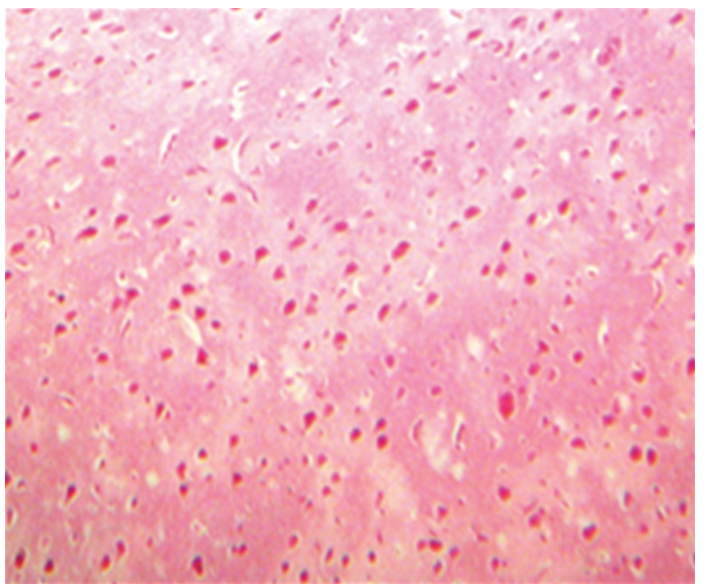

(c)

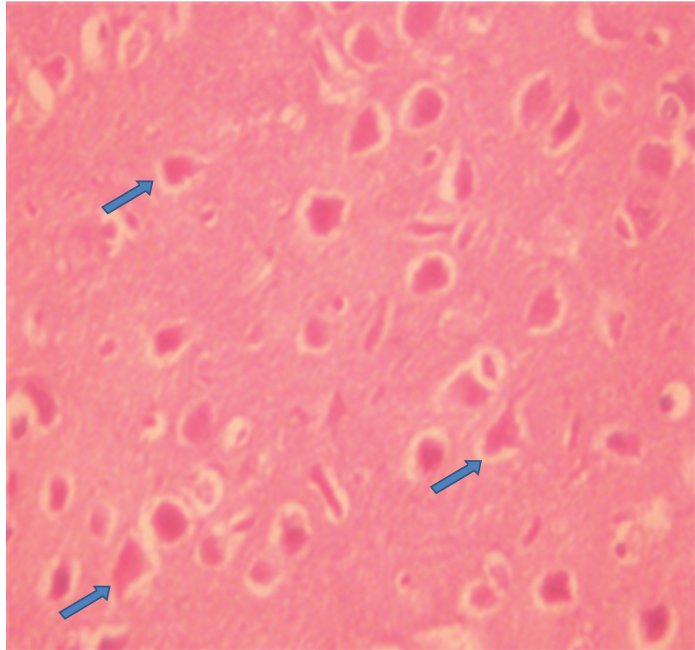

(b)

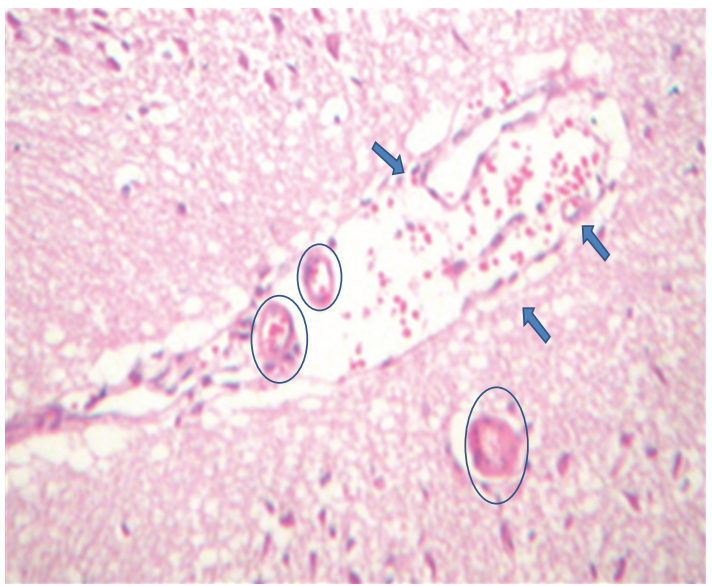

(d)

FIGURE 2: Brain of control group (a and b). (a) The neuroepithelium (bold arrow) is of normal cellularity and architecture, with the supportive astroglial tissue (thin arrow) at $\times 100$ ( $\mathrm{H}$ and $\mathrm{E}$ ). (b) The astro-glial tissue is of normal cellularity, showing pyramidal astroglial cells, with indistinct cell boundaries, having fibrillary cytoplasmic processes (arrows) at $\times 400$ ( $\mathrm{H}$ and $\mathrm{E}$ ). Brain of exposed group (c and d). (c) The field shows marked astro-glial hypercellularity (i.e., reactive gliosis) at $\times 200$ (H and E). (d) The astro-glial tissue shows marked hypercellularity (i.e., secondary reactive gliosis), with a diffused vascular congestion (arrows) accompanied by extravasation of RBCs, as well as partial obliteration of lumen with thickened hypertrophied fibrous vessel wall (encircled) at $\times 300(\mathrm{H}$ and $\mathrm{E})$.

TABLE 2: DNA damage in the brain of newborn rats after whole body exposure to $50 \mathrm{~Hz}$ and $0.5 \mathrm{mT}$ MF for 30 days $24 \mathrm{~h} /$ day, assessed by comet assay. Each value was expressed as mean of 10 rats \pm standard error.

\begin{tabular}{|c|c|c|c|c|c|c|}
\hline \multirow{2}{*}{ Groups } & \multicolumn{6}{|c|}{ Grade of damage } \\
\hline & Type (0) & Type (1) & Type (2) & Type (3) & Type (4) & Types $(2+3+4)$ \\
\hline Control & $49.3 \pm 0.67$ & $28.7 \pm 2.196$ & $15.3 \pm 0.33$ & $6.7 \pm 0.33$ & 0 & $22 \pm 0.57$ \\
\hline Exposed & $17.3 \pm 0.67^{* *}$ & $43.3 \pm 2.31^{*}$ & $19.7 \pm 0.33^{* *}$ & $13.7 \pm 0.88^{* *}$ & $6 \pm 0.58^{* * *}$ & $39.3 \pm 1.76^{* *}$ \\
\hline
\end{tabular}

$*, * *, * * *$ Significant difference in comparison with the corresponding control at $\alpha=0.01,0.001$, and 0.0001 , respectively.

by the mitotic index (MI), which is the number of dividing cells in 1000 cells per rat.

2.8. Statistical Analysis. All statistical analysis were executed by the aid of Statistical Package for the Social Science (SPSS) version 20. In order to compare between various variables (control and exposed), student $t$-test was used at $\alpha=0.05$, $0.01,0.001$, and 0.0001 .

\section{Results}

The measured malondialdehyde (MDA), glutathione (GSH), and super oxidedismutase (SOD) levels in brain cells of 


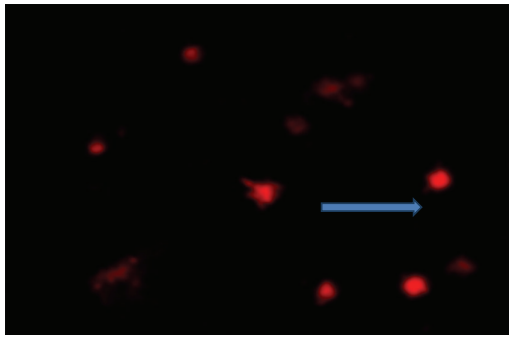

(a)

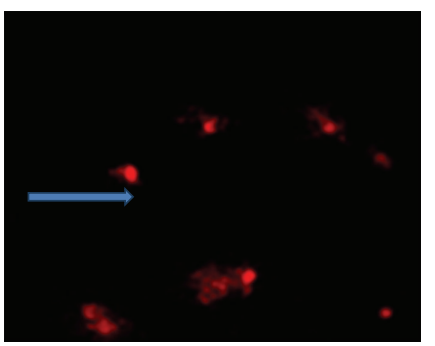

(b)

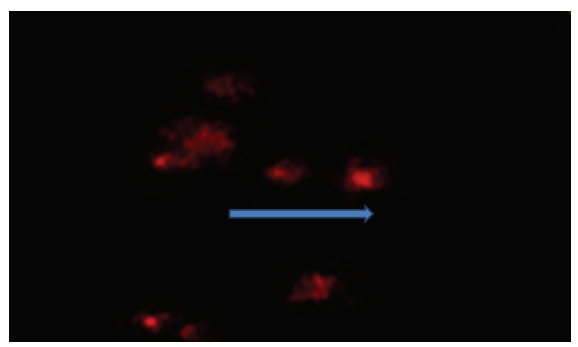

(c)

FIgURe 3: Evaluation of DNA damage induced by $50 \mathrm{~Hz}$ and $0.5 \mathrm{mT}$ MF for 30 days $24 \mathrm{~h}$ /day in the brain cells of newborn rats processed by comet assay. (a) represents cells without visible DNA damage type (0), (b) represents cells with symptom of increasing DNA damage types (1,2, and 3), and (c) represents cells with a major DNA damage (type 4$)$.

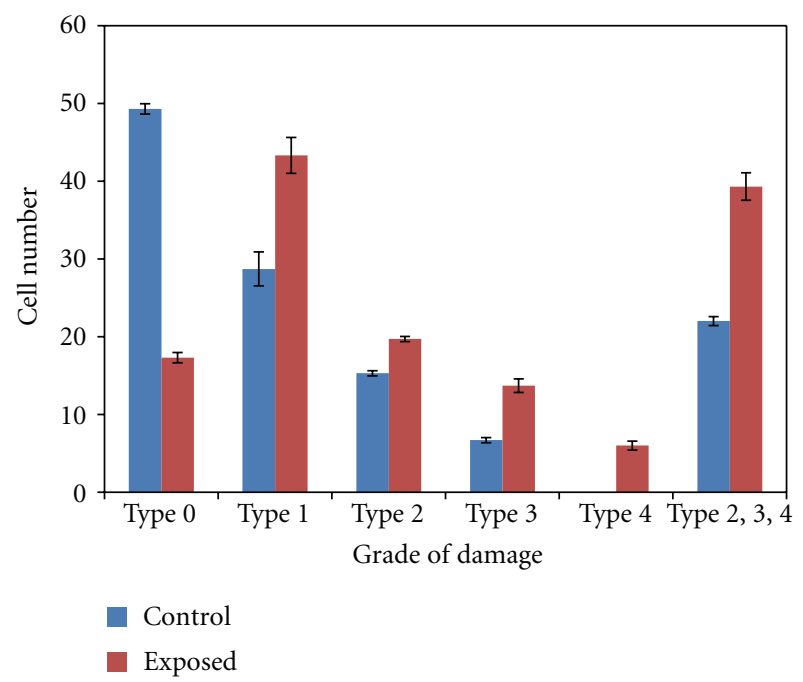

Figure 4: The level of DNA damage in brain cells of control newborn rats and those exposed to $50 \mathrm{~Hz}$ and $0.5 \mathrm{mT}$ MF for 30 days $24 \mathrm{~h}$ /day. Assessed by comet assay. Mean \pm S.E. $(P<0.05)$.
TAble 3: Micronucleus induction (MNPCE), PCE, and NCE in bone marrow cells of control newborn rats and those exposed to $50 \mathrm{~Hz}$ and $0.5 \mathrm{mT}$ MF for 30 days $24 \mathrm{~h}$ /day. Each value was expressed as mean of 10 rats \pm standard error.

\begin{tabular}{lccc}
\hline Groups & NCE/100 & PCE/100 & MNPCE/2000 \\
\hline Control & $60.67 \pm 1.53$ & $39.33 \pm 1.53$ & $17.6 \pm 0.58$ \\
Exposed & $56.33 \pm 0.58^{*}$ & $43.67 \pm 0.58^{*}$ & $72 \pm 3.61^{* *}$ \\
\hline
\end{tabular}

$*, * *$ Significant difference in comparison with the corresponding control at $\alpha=0.01$ and 0.001 , respectively.

TABle 4: Mitotic index in bone marrow cells of control newborn rats and those exposed to $50 \mathrm{~Hz}$ and $0.5 \mathrm{mT} \mathrm{MF}$ for 30 days $24 \mathrm{~h} /$ day. Each value was expressed as mean of 10 rats \pm standard error.

\begin{tabular}{lc}
\hline Group & MI/1000 cells \\
Control & $26 \pm 3$ \\
Exposed & $65 \pm 2.65^{*}$ \\
\hline${ }^{*}$ Signifant
\end{tabular}

* Significant difference in comparison with the corresponding control at $\alpha=0.0001$.

newborn rats for the two groups were listed in Table 1. For exposed group when compared with control one, a significant increase in the MDA and SOD levels was observed $(P<0.05)$. In contrast ELF-MF failed to alter GSH level.

Brain section of control group showed fibrillar matrix and normal vasculature. No necrodegenerative or atrophic changes appeared. Also, there are no vascular or inflammatory lesions with the absence of gliosis (i.e., no astroglial proliferation) Figures 2(a) and 2(b). Meanwhile Figures 2 (c) and 2(d) showed the brain section of exposed group revealing mild atrophy and degeneration within the glia. Moreover, reactive gliosis appeared accompanied by mild vascular congestion.

The levels of DNA damage in brain cells of exposed newborn rats showed a significant increase $(P<0.01,0.001$, 0.0001 ) compared to control one (Table 2 and Figures 3 and $4)$. For type (0) the data revealed that about $50 \%$ of brain cells did not exhibit any DNA damage in control group compared to $17 \%$ for exposed one. Meanwhile in type (4) about $6 \%$ of brain cells showed complete DNA damage in exposed group relative to $0 \%$ for control one. The total percent of DNA damage in brain cells represented by types (2, 3 and 4) showed two-fold increase for exposed group with respect to control one.

Table 3 and Figure 5 showed the frequencies of MNPCE, PCE, and NCE in bone marrow cells of newborn rats for both control and exposed groups. The results showed a significant increase in the formation of PCE and MNPCE, respectively, $(P<0.01$ and $P<0.001)$ for exposed group compared to control one.

The results of the mitotic index (used to evaluate cell cycle kinetics) are summarized in Table 4 and Figure 6. The results showed that MI of bone marrow cells exposed to ELF$\mathrm{MF}$ was increased significantly compared to the control one $(P<0.0001)$. 


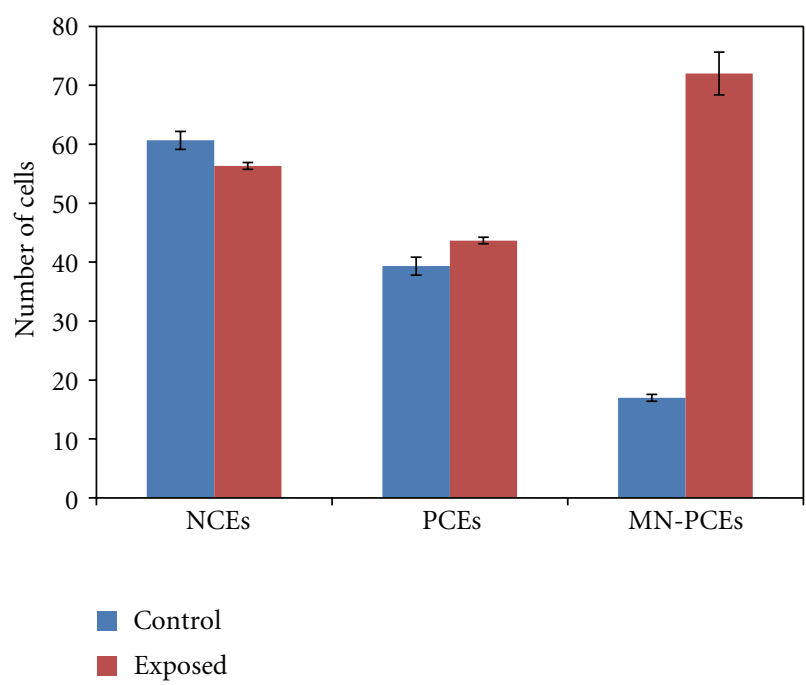

Figure 5: Micronucleus induction, NCE, PCE, and MN-PCE, in bone marrow cells of control newborn rats and those exposed to $50 \mathrm{~Hz}$ and $0.5 \mathrm{mT}$ MF for 30 days $24 \mathrm{~h} /$ day. Mean \pm S.E. $(P<0.01$, $0.001)$ for PCE and MNPCE, respectively.

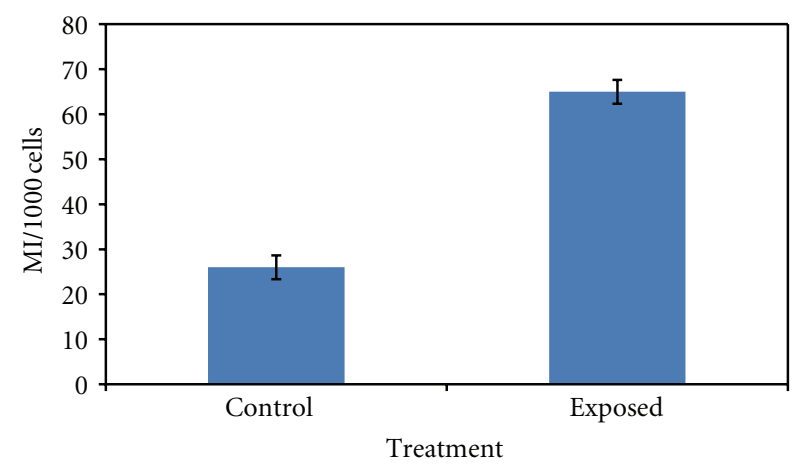

FIGURE 6: Mitotic index in bone marrow cells of control newborn rats and those exposed to $50 \mathrm{~Hz}$ and $0.5 \mathrm{mT}$ MF for 30 days $24 \mathrm{~h} /$ day. Mean \pm S.E. $(P<0.001)$.

\section{Discussion}

Health concerns about exposure to ELF-MF are particularly significant in children due to its potential harmful outcomes. It is generally accepted that ELF-MF is unable to transfer energy to cells in sufficient amounts that may cause direct cytotoxic and genotoxic effects. However, it is possible that certain cellular processes such as free radicals production and/or activity are altered by exposure to ELF-MF [27]. Thus, antioxidant activity, DNA damage, micronucleus induction, and cellular damage are probably induced by indirect mechanisms. In agreement with previous literature $[28,29]$, our results showed a significant increase in the main antioxidant enzymatic activities in the brain cells of exposed newborn rats which was considered as an evidence for occurrence of a physiological disturbance. Such increase of MDA and SOD levels means the presence of lipid peroxidation and oxidative stress. Accordingly, ELFMF may induce oxygen free radicals which can evoke an interaction with membrane lipids, proteins, and nucleic acids leading to extensive tissue damage that was confirmed by histopathological examination (Table 1 and Figure 2).

The results emphasized that exposing newborn rats to ELF-MF significantly increases the number of cells with damaged DNA types $(2,3$, and 4) compared to the control one (Figures 3, 4 and Table 2). This damage might be due to the excess of oxygen derived from free radicals. These findings are in consistent with Lai and Singh $[3,4]$ who hypothesized that magnetic field $(60 \mathrm{~Hz}, 0.1,0.25$, and $0.5 \mathrm{mT}, 24 \mathrm{hr}$ exposure) could damage DNA by radical pairs mechanism that cause an increase in the number of single strand breaks in brain cells of the rat. Supportive to this hypothesis is their observation that DNA breaks were blocked by free radicals scavengers (melatonin and $\mathrm{N}-\mathrm{t}$ butyl- $\alpha$ phenylnitrone).

Free radical activity and DNA breaks may be considered as the main causes of the significant increase (Table 3 and Figure 5) in the micronucleus induction of newborn rats bone marrow, and similar results were previously reported $[30,31]$. Also Lai and Singh $[4,32]$ reported that reactive oxygen species (ROS) interact with the spindle apparatus and cause micronucleus induction.

In the current study, the significant increase in mitotic index (Table 4 and Figure 6) measurements may be attributed to the enhancement effect of ELF-MF on $\mathrm{Ca}^{++}$ions flux throughout the cell membrane [33].

\section{Conclusion}

The current study showed that continuous exposure of newborn rats to $50 \mathrm{~Hz}$ and $0.5 \mathrm{mT}$ MF for 30 days $24 \mathrm{~h}$ /day led to cytogenetic and genotoxic hazards. Our results strongly demonstrate that chronic exposure of newborn rats can induce serious DNA damage that may lead to genomic instability, leading to carcinogenesis. Future studies about the health risks of ELF-MFs should be extended to evaluate the other physiological disturbances that might occur due to daily environmental exposure.

\section{Conflict of Interests}

The authors report no conflict of interests. The authors alone are responsible for the content and writing of the paper.

\section{References}

[1] N. Wertheimer and E. Leeper, "Original contributions. Electrical wiring configurations and childhood cancer," American Journal of Epidemiology, vol. 109, no. 3, pp. 273-284, 1979.

[2] H. Berg, "Problems of weak electromagnetic field effects in cell biology," Bioelectrochemistry and Bioenergetics, vol. 48, no. 2, pp. 355-360, 1999.

[3] H. Lai and N. P. Singh, "Acute exposure to a $60 \mathrm{~Hz}$ magnetic field increases DNA strand breaks in rat brain cells," Bioelectromagnetics, vol. 18, no. 2, pp. 156-165, 1997.

[4] H. Lai and N. P. Singh, "Melatonin and N-tert-butyl- $\alpha$ phenylnitrone block $60 \mathrm{~Hz}$ magnetic field-induced DNA single 
and double strand breaks in rat brain cells," Journal of Pineal Research, vol. 22, no. 3, pp. 152-162, 1997.

[5] B. M. Svedenstål, K. J. Johanson, and K. Hansson Mild, "DNA damage induced in brain cells of CBA mice exposed to magnetic fields," In Vivo, vol. 13, no. 6, pp. 551-552, 1999.

[6] B. M. Svedenstål, K. J. Johanson, M. O. Mattsson, and L. E. Paulsson, "DNA damage, cell kinetics and ODC activities studied in CBA mice exposed to electromagnetic fields generated by transmission lines," In Vivo, vol. 13, no. 6, pp. 507-513, 1999.

[7] H. Yaguchi, M. Yoshida, G. R. Ding, K. Shingu, and J. Miyakoshi, "Increased chromatid-type chromosomal aberrations in mouse m5S cells exposed to power-line frequency magnetic fields," International Journal of Radiation Biology, vol. 76, no. 12, pp. 1677-1684, 2000.

[8] R. Pasquini, M. Villarini, G. Scassellati Sforzolini, C. Fatigoni, and M. Moretti, "Micronucleus induction in cells co-exposed in vitro to $50 \mathrm{~Hz}$ magnetic field and benzene, 1,4-benzenediol (hydroquinone) or 1,2,4-benzenetriol," Toxicology in Vitro, vol. 17, no. 5-6, pp. 581-586, 2003.

[9] D. D. Ager and J. A. Radul, "Effect of $60 \mathrm{~Hz}$ magnetic fields on ultraviolet light-induced mutation and mitotic recombination in Saccharomyces cerevisiae," Mutation Research, vol. 283, no. 4, pp. 279-286, 1992.

[10] A. Antonopoulos, B. Yang, A. Stamm, W. D. Heller, and G. Obe, "Cytological effects of $50 \mathrm{~Hz}$ electromagnetic fields on human lymphocytes in vitro," Mutation Research, vol. 346, no. 3, pp. 151-157, 1995.

[11] S. Amara, H. Abdelmelek, C. Garrel et al., "Influence of static magnetic field on cadmium toxicity: Study of oxidative stress and DNA damage in rat tissues," Journal of Trace Elements in Medicine and Biology, vol. 20, no. 4, pp. 263-269, 2006.

[12] J. Everse and N. Hsia, "The toxicities of native and modified hemoglobins," Free Radical Biology and Medicine, vol. 22, no. 6, pp. 1075-1099, 1997.

[13] B. A. Freeman and J. D. Crapo, "Biology of disease. Free radicals and tissue injury," Laboratory Investigation, vol. 47, no. 5, pp. 412-426, 1982.

[14] N. Hogg and B. Kalyanaraman, "Nitric oxide and lipid peroxidation," Biochimica et Biophysica Acta, vol. 1411, no. 23, pp. 378-384, 1999.

[15] S. Di Loreto, S. Falone, V. Caracciolo et al., "Fifty hertz extremely low-frequency magnetic field exposure elicits redox and trophic response in rat-cortical neurons," Journal of Cellular Physiology, vol. 219, no. 2, pp. 334-343, 2009.

[16] National Research Council, Guide for the Care and Use of Laboratory Animals, National Academy Press, Washington, DC, USA, 1996.

[17] M. Nishikimi, N. Appaji Rao, and K. Yagi, "The occurrence of superoxide anion in the reaction of reduced phenazine methosulfate and molecular oxygen," Biochemical and Biophysical Research Communications, vol. 46, no. 2, pp. 849-854, 1972.

[18] E. Beautler, O. Duron, and B. M. Kelly, "Improved method for the determination of blood glutathione.," The Journal of Laboratory and Clinical Medicine, vol. 61, pp. 882-888, 1963.

[19] M. Uchiyama and M. Mihara, "Determination of malonaldehyde precursor in tissues by thiobarbituric acid test," Analytical Biochemistry, vol. 86, no. 1, pp. 271-278, 1978.

[20] P. Moller, L. E. Knudsen, S. Loft, and H. Wallin, "The comet assay as a rapid test in biomonitoring occupational exposure to DNA-damaging agents and effect of confounding factors," Cancer Epidemiology Biomarkers and Prevention, vol. 9, no. 10, pp. 1005-1015, 2000.
[21] W. M. Awara, S. H. El-Nabi, and M. El-Gohary, "Assessment of vinyl chloride-induced DNA damage in lymphocytes of plastic industry workers using a single-cell gel electrophoresis technique," Toxicology, vol. 128, no. 1, pp. 9-16, 1998.

[22] N. P. Singh, M. T. McCoy, R. R. Tice, and E. L. Schneider, "A simple technique for quantitation of low levels of DNA damage in individual cells," Experimental Cell Research, vol. 175, no. 1, pp. 184-191, 1988.

[23] R. Tice, E. Agurell, D. Anderson et al., "Single cell gel/comet assay: guidelines for in vitro and in vivo genetic toxicology testing," Environmental and Molecular Mutagenesis, vol. 35, no. 3, pp. 206-221, 2000.

[24] W. Schmidt, "The micronucleus test for cytogenetic analysis," in Chemical Mutagens, Principles and Methods for Their Detection, A. Hollaender, Ed., pp. 31-53, Plenum Press, New York, NY, USA, 1976.

[25] D. K. Agarwal and L. K. S. Chauhan, "An improved chemical substitute for fetal calf serum for the micronucleus test," Biotechnic and Histochemistry, vol. 68, no. 4, pp. 187-188, 1993.

[26] I. Adler, "Cytogenetic tests in mammals," in Mutagenicity Testing, A Practical Approach, S. Venitt and J. M. Parry, Eds., pp. 275-306, IRL Press, Oxford, UK, 1984.

[27] B. Brocklehurst and K. A. McLauchlan, "Free radical mechanism for the effects of environmental electromagnetic fields on biological systems," International Journal of Radiation Biology, vol. 69, no. 1, pp. 3-24, 1996.

[28] B. Zheng, G. Yao, L. Xie, Y. Lin, D. Q. H. Lu, and Chiang, "Effects of $50 \mathrm{~Hz}$ magnetic fields on lipid peroxydation and antioxidase activities in brain tissue of mice," in Proceedings of the 2nd World Congress for Electricity and Magnetism in Biology and Medicine, 1997.

[29] T. B. Kryston, A. B. Georgiev, P. Pissis, and A. G. Georgakilas, "Role of oxidative stress and DNA damage in human carcinogenesis," Mutation Research, vol. 711, no. 1-2, pp. 193-201, 2011.

[30] I. Udroiu, M. Cristaldi, L. A. Ieradi, A. Bedini, L. Giuliani, and C. Tanzarella, "Clastogenicity and aneuploidy in newborn and adult mice exposed to $50 \mathrm{~Hz}$ magnetic fields," International Journal of Radiation Biology, vol. 82, no. 8, pp. 561-567, 2006.

[31] L. Dominici, M. Villarini, C. Fatigoni, S. Monarca, and M. Moretti, "Genotoxic hazard evaluation in welders occupationally exposed to extremely low-frequency magnetic fields ( ELF-MF)," International Journal of Hygiene and Environmental Health, vol. 215, no. 1, pp. 68-75, 2011.

[32] H. Lai and N. P. Singh, "Magnetic field-induced DNA strand breaks in brain cells of the rat," Environmental Health Perspectives, vol. 112, no. 6, pp. 687-694, 2004.

[33] A. Lacy-Hulbert, J. C. Metcalfe, and R. Hesketh, "Biological responses to electromagnetic fields," FASEB Journal, vol. 12, no. 6, pp. 395-420, 1998. 

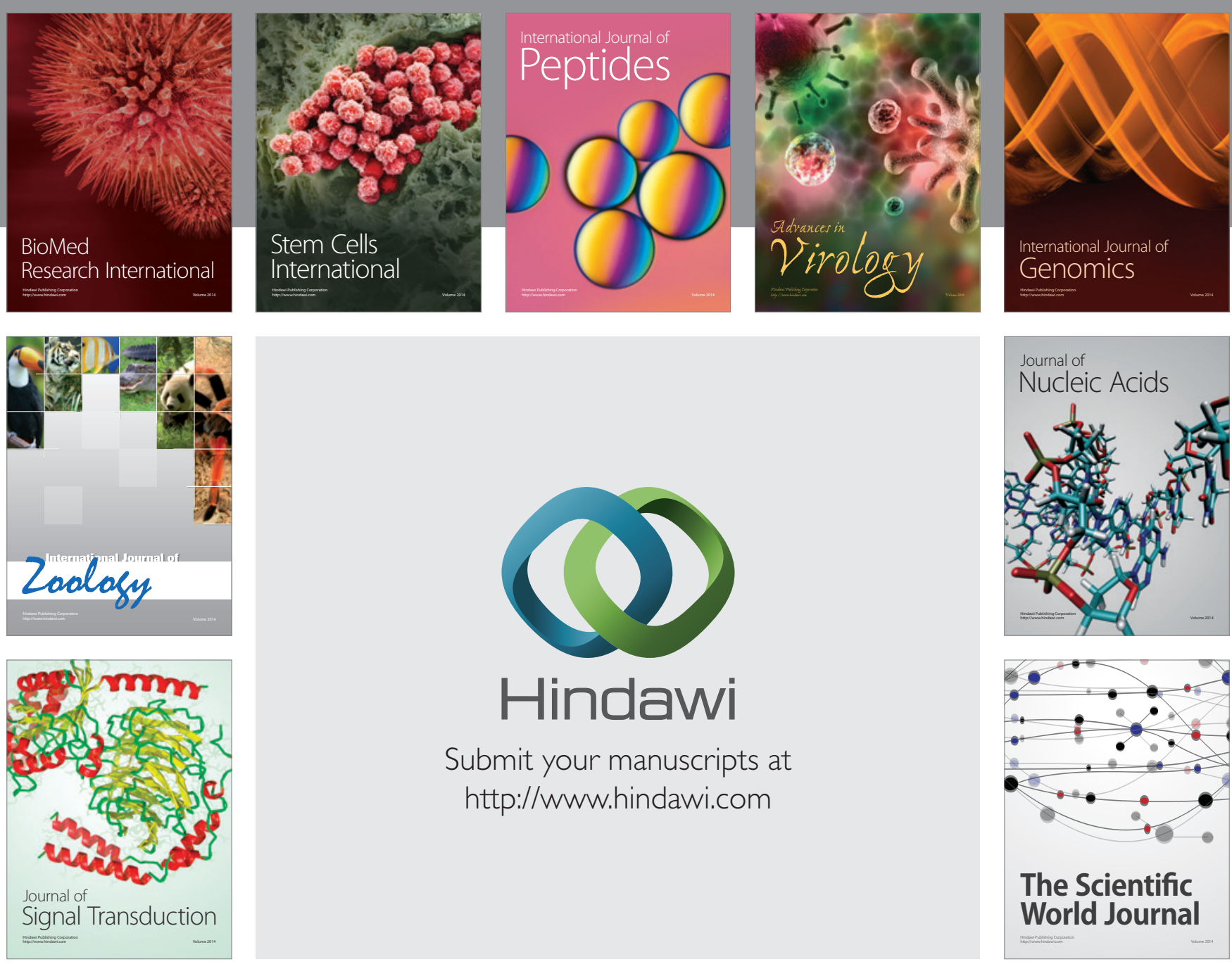

Submit your manuscripts at

http://www.hindawi.com
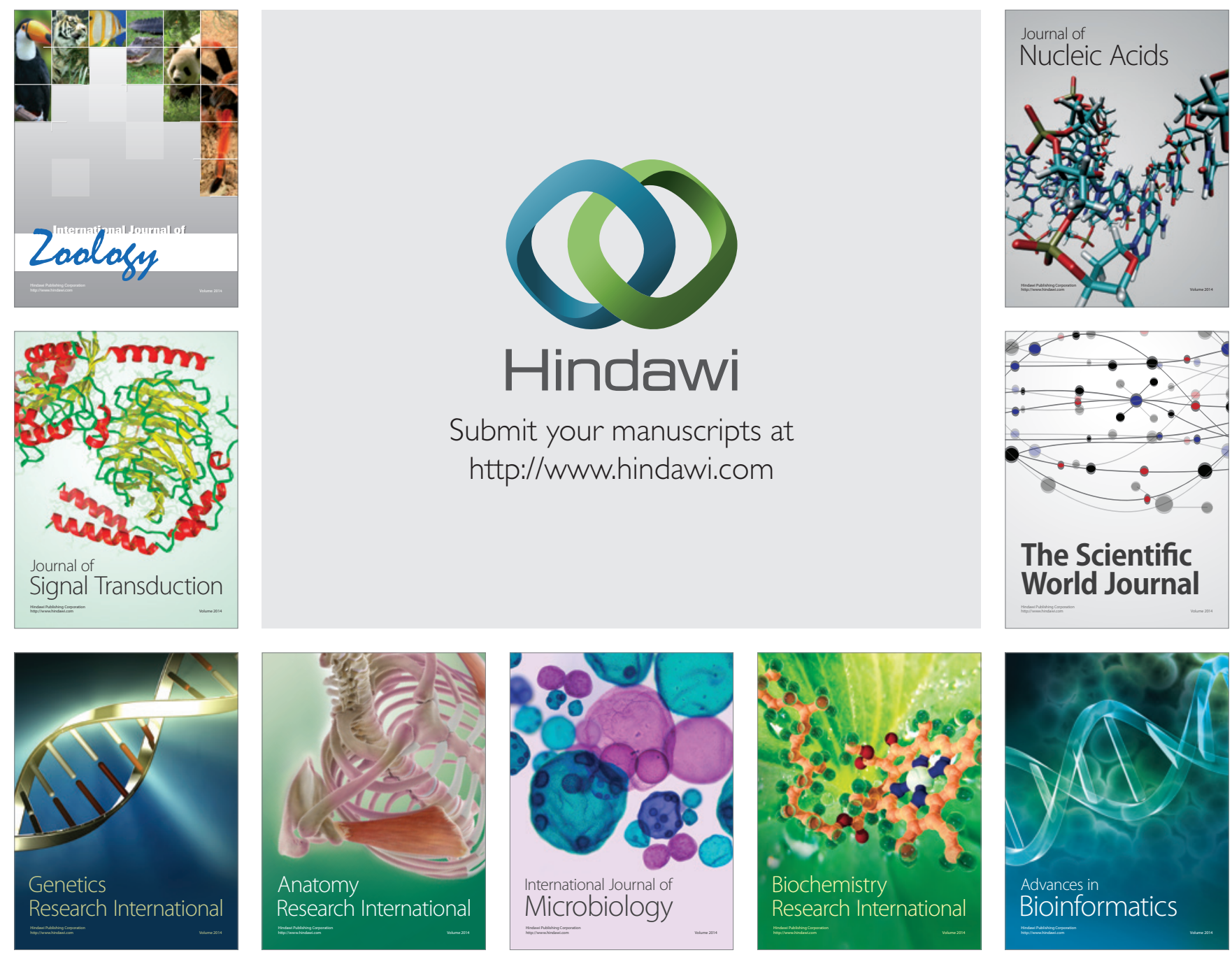

The Scientific World Journal
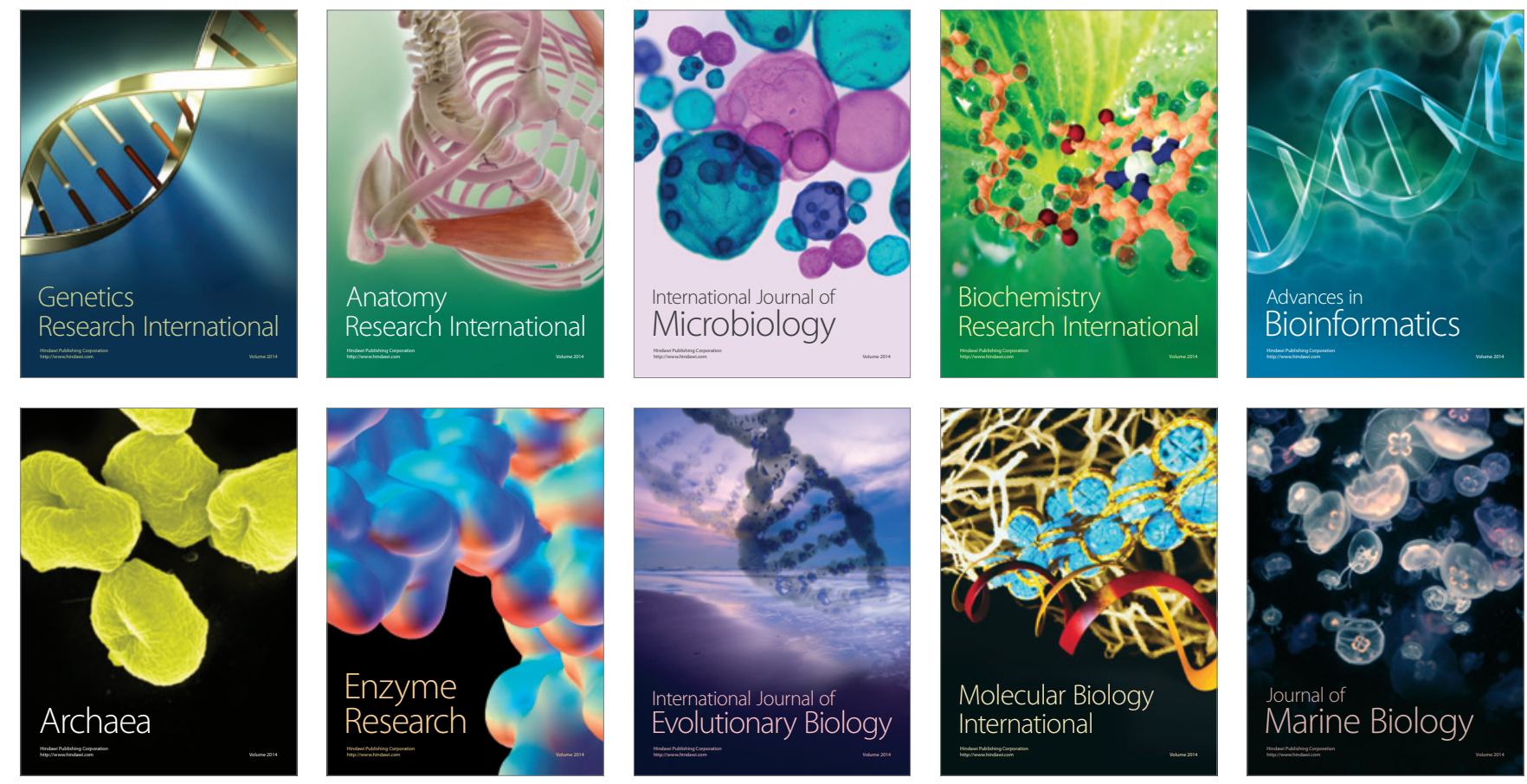